\title{
Double honour for fellow Gerd Wegener
}

\author{
John Barnett
}

Published online: 29 October 2009

(C) Springer-Verlag 2009

The outstanding research of Professor Wegener, presently Head of the Department of Wood Science and Technology at the Technische Universität München has been recognised by two Achievement Awards for his life's work. He has been presented with the Cross of the Order of Merit of the Federal Republic of Germany and the Schweighofer Prize.

At a major ceremony on 18th June, attended by 500 guests from over 30 nations, he was awarded the "Schweighofer Prize 2009" in the Vienna City Hall. This award for innovation, founded by the Austrian wood industry dynasty Schweighofer, is the most highly endowed European Award for the wood and timber industry. The citation for the award included the statement that "his innumerable innovative research approaches have led to new developments and have inspired generations of scientists and traders in the wood and timber industry".

The Cross of the Order of Merit of the Federal Republic of Germany was decreed by the Federal President of Germany and Fellow Wegener received the appendant regalia - order and document on 3rd July 2009 from the Bavarian Minister of Agriculture, Helmut Brunner in a ceremony at the Ministry of State for Food, Agriculture and Forestry.

The minister referred to Prof. Wegener as one of the most invaluable "ambassadors for the increased application of wood and wood products". The Cross of the Order of Merit of the Federal Republic of Germany is well-deserved recognition of his exemplary commitment towards the Bavarian Wood and Forest Industry.

The congratulations of the Academy are offered to Fellow Wegener on these well-earned rewards.

\section{EC meeting and workshop in Rabat}

The next Executive Committee meeting of IAWS will take place at a joint international workshop with the Ecole des Sciences et Technologies du Bois at the 
Mohamed V-Agdal University Faculty of Sciences in Rabat, Morocco, from 22 to 25 March 2010. The theme of the workshop will be "Wood and Derivatives: Sustainable materials and products for future needs". A limited number of participants will be welcomed and further information may be obtained from Xavier Deglise, Xavier.Deglise@ lermab.uhp-nancy.fr.

John Barnett

Past President of IAWS 